\title{
Effectiveness of Food Safety Awareness Program to Build Early Childhood Development
}

\author{
$1^{\text {st }}$ Bertakalswa Hermawati \\ Public Health Science \\ Department \\ Faculty of Sports Science \\ Universitas Negeri Semarang \\ Semarang, Indonesia \\ bertahermawati@gmail.com
}

\author{
$2^{\text {nd }}$ Sofwan Indarjo \\ Public Health Science \\ Department \\ Faculty of Sports Science \\ Universitas Negeri Semarang \\ Semarang, Indonesia \\ sofwan_indarjo@yahoo.co.id
}

\author{
$3^{\text {rd }}$ Efa Nugroho \\ Public Health Science \\ Department \\ Faculty of Sports Science \\ Universitas Negeri Semarang \\ Semarang, Indonesia \\ efa.nugroho@mail.unnes.ac.id
}

\author{
$4^{\text {th }}$ Dyah Mahendrasari Sukendra \\ Public Health Science \\ Department \\ Faculty of Sports Science \\ Universitas Negeri Semarang \\ Semarang, Indonesia \\ dyahmahendra@yahoo.com
}

\begin{abstract}
The objectives of this study was to determine the change of mother's behavior after given intervention related to food safety in early childhood. The study design was before and after experimental design. The sample were 62 mothers. Intervention with educational model through film media related with food safety aspects. The instrument was a questionnaire. Data analysis using t-test. The results showed that there was a significant change. It can be concluded that there is an improvement in mother's behavior after being given intervention.
\end{abstract}

Keywords - food safety awareness, education model, behavior change

\section{INTRODUCTION}

To enhance the physical development of children according to his age that needed the proper nutrition and food safety to be consumed by the child. The World Health Organization (WHO) emphasizes that food safety is an act to ensure all foods are safe for consumption [1]. In this case, it includes how to protect kids from choking hazards [2]. According to WHO, there are 1.5 billion cases of diarrhea worldwide (except in China), estimated at $70 \%$ relating to food consumption and a related 1.8 million deaths in children under the age of five [1].

In Indonesia, more than $40 \%$ of foodborne diseases are in children under five years [3]. In line with data cases of foodborne illness in early childhood children at kindergarten and preschool located in Petompon area in 2017 showed that 167 cases of influenza, 3 cases of vomiting and diarrhea and 2 cases of inflammation. Foodborne disease cases occur from exposures outside the home and home. Currently, research in Indonesia still focuses on food prepared outside of the home, while relating to food safety in home is still limited.

The factors influencing food safety are pollution caused by microorganisms such as bacteria, chemicals in food on certain food processing, and physical contaminants include dirt, hair, nail polish flakes, insects, broken glass, nails, staples, plastic,dust, flies. In under developed countries, food poisoning is caused by unhygienic conditions, lack of hygiene education, drought, contaminated water, improper food storage conditions, pesticide residues, dirty environment and improperly maintained [4].

Based on the above statement, food safety related to knowledge and behavior. The results of a 2000 Home Food Safety Study conducted by Audits Internationals that food safety mistakes are caused by $40 \%$ lack of knowledge, $40 \%$ lack of awareness and 20\% lack of motivation [5]. In addition, the results of research by [6] indicate that knowledge and practice of food safety in housewives in Yogyakarta city is low. A recent review also implicates a lack of food preparation knowledge as barriers to prepare home cooked-meals [7]. The Health Belief Model also supports the above research results. This theory suggests that knowledge influences trust to vulnerability and severity of disease, benefits and barriers to practicing preventive health behaviors, and self-efficacy [8].

In many families, mothers have main responsibility for feeding children[9]. The child will learn to observe from the mother and putting knowledge into practice to prevent unsafe food [5].

The effort to increase food safety awareness for mother is educational methods. This methods aim for understanding and changing behavior. Educational methods which effectively to coach the mothers are film and discussion. The methods are more effective in giving awareness to change the behavior[10]. Based on an example or model, a person receives knowledge about the proper behavior as well as a guide in behaving [11]. Behavior is defined as everything that a person does or says. Behavior can be attributed to activities, actions, performance, responses, responses and reactions. Technically, behavior is related to muscle function, gland, human body electrical activity [12]. In this case the behavior is all the practices done by someone in the form of words and actions. Characteristics of behavior that can be measured through behavioral dimensions are frequency and duration [12].In addition, the habits can be formed after 66 days[13]. 


\section{MATERIALS AND METHODS}

Characteristics of the population in this study were mothers with children aged 3-5 years in Petompon, Semarang, Indonesia. The sampling technique is the judgmental or purposive sampling technique that is taken based on the need to achieve the purpose of this research $[14,15]$. As the sample of this study is 168 mothers of 3-5 year old children who are currently following the activities studying in Aisyiyah Preschool, ABA Kindergarten and Pembina Preschool and Kindergarten. The qualified sample in the end of the research or follow the instruction and response the questionnaires properly before and after intervention are 62 mothers.

This study uses before and after experimental design [14, 15]. In this study, maternal behavioral issues related to food safety were intervened with food safety awareness as an educational model. It has several aspects of food safety messages using film and booklet. The film is viewed once at beginning research, while booklet is distributed to mother to take home. It aims to remind the food safety messages. After film viewing, the participants are facilitated to discuss about the messages. In the end of intervention, it can be measured and observed the impacts through behavior changes. The questionnaire has been tested reliability and validity. The aspects of questionnaire include how to keep the hands clean, how to keep tableware and cutlery and kitchen clean, food preparation and food handling, how to avoid the food that contain toxic additives, and how to prevent choking. The scale of questionnaire refers to the components of behavior, they are frequency and duration. Frequency refers to how many behaviors occur in a period. While the duration refers to how long the behavior occurs in certain periods [12]. Data analysis using paired sample $t$ test to test the hypothesis of two samples in numerical data (interval or ratio)

\section{RESULTS AND DISCUSSION}

TABLE I.

CHARACTERISTIC OF RESPONDENT

\begin{tabular}{|c|l|c|c|}
\hline Characteristic & \multicolumn{1}{|c|}{ Variable } & Respondent & Percentage \\
\hline \multirow{3}{*}{ Maternal status } & House wife & 24 & $39 \%$ \\
\cline { 2 - 4 } & $\begin{array}{l}\text { Working } \\
\text { mother }\end{array}$ & 37 & $61 \%$ \\
\hline \multirow{3}{*}{$\begin{array}{c}\text { Food handler in } \\
\text { household }\end{array}$} & Mother & 50 & $81 \%$ \\
\cline { 2 - 4 } & Grandmother & 5 & $8 \%$ \\
\cline { 2 - 4 } & Spouse & 3 & $5 \%$ \\
\cline { 2 - 4 } & $\begin{array}{l}\text { Household } \\
\text { assistant }\end{array}$ & 4 & $6 \%$ \\
\hline
\end{tabular}

Respondent characteristic data showed the most maternal status were working mother $(61 \%)$ and majority of food handler was mother (81\%) and the others are $8 \%$ of grandmother, $5 \%$ were spouse/husband and household assistant $(6 \%)$.

TABLE II. STATISTICAL TEST RESULT

\begin{tabular}{|l|c|c|}
\hline Food Safety Behavior & Mean & Sd \\
\hline Before & 53 & 3.4 \\
\hline After & 54 & 2.7 \\
\hline t-test score value & \multicolumn{2}{|c|}{0,000} \\
\hline
\end{tabular}

By Wilcoxon signed rank test, the result indicated that mean respondents behavior before intervention were 53 and after intervention were 54 with $\mathrm{p}$ value 0.000 .

Based on the analysis of questionnaire data, the descriptions of respondents behavior in several aspects revealed :1) the behavior to prevent chocking achieve $100 \%, 2$ ) the behavior to keep tableware and cutlery and kitchen clean were $90 \%, 3$ ) the behavior to avoid the food that contain toxic additives were $90 \%, 4$ ) the behavior to prepare and handle the food were $70 \%$ and 5) $65 \%$ of the behavior to keep hands clean.

Health promotion can be delivered through various mass media, both print and electronic media. Each media has its advantages and disadvantages, that the proper media selection in order to get maximum results is needed [16]. The results showed the effectiveness of the Food Safety Awareness Program model using the selected film media is customized to the mother of preschool and kindergarten students. Increased behavior in terms of food safety management after intervention and statistics illustrate that there are any differences before and after intervention, and the model is effective.Although a person's or society's behavior on health is determined by many factors, such as knowledge, attitudes, beliefs, traditions, education, the economic or social level, but the effort in providing health promotion is a basic effort that must be considered. Besides, the availability of facilities, attitudes and behavior of health workers will also support and strengthen the formation of a behavior or action[17].

It is expected that the educational media through film can encourage the improvement of mother's behavior toward food safety.The effectiveness of a film as an educational media can be realized depends on the elements of the film itself and choosing the right strategy in message delivery. In addition, in the delivery of films, it should be noted also how a facilitator needs to deliver the advantages if the action is done. Educational media can raise awareness for the mother about the importance of providing safe and hygienic food for children according to minimize disease. Mothers can practice the examples to manage and provide food safety for children. In line with recent research, that the film is proved in promoting positive behavior effectively[10]. This is also substantiated by other research that film is more effective to increase the practices in child care [18].

In the discussion, there are many questions from the participants and mainly related with food preparation and food handling. In this activity, the participants can discuss and gain an adequate knowledge related to food safety. In accordance with the results of the study that $36 \%$ of food handlers do not have an adequate knowledge about hygienic and food safety. Sources of information are generally obtained by friends, mass media, parents, health supervisors, and training [19]. However sources of information by from friends, mass media and parents tend to be less accurate than by health supervisors and training. Hence, food safety awareness program is important to be given to all mothers 
The results of this study also show that $90 \%$ of mothers (working mother $61 \%$ or housewife $31 \%$ ) keep play a role in food preparation and food handling for children, and the others are grandmother, father and household assistant. This is due to the fact that the most of mothers have understood to their role to pay attention for children health. It is in line with the statement that the first function of the mother is to provide physical care for the child, mainly in feeding of children[20].

The mothers could focus their attention during the right stages of early childhood.It is a period marked by rapid physical and neurological development and vulnerability to health risks. In addition, the children are also in a very sensitive condition to the stimulus so that they are easily guided, directed, and inculcated good and bad habits. Collaboration between parents and school institutions can be utilized for community empowerment. It can foster independence community. This is according to the results of the research that empowerment can be droved by parents, communities and institutions [21].

This study showed that the main problem of food safety is on the aspect of keeping hands clean. Our research is concern in how hand washing behavior is appropriate. It includes how hand washing behavior and the length of time used to wash hands. Food handler requires to wash their hands to inhibit microorganisms before touching the food. Other research found that handwashing before preparing food is a particularly important opportunity to prevent childhood diarrhea, and that handwashing with water alone can significantly reduce childhood diarrhea[22]. Hand washing effectively reduces the spread of infectious diseases by bacteria, parasites and viruses [23].

\section{CONCLUSION}

This study found that there were differences before and after Food Safety Program intervention model. There are improvement better that this model has an effective value. Respondents have understood its role in food management and its importance in managing food to be safe from bacteria and other pollution. Consistency in carrying out food safety practices is important in daily life. In addition, the results support on the hypothesis that the provision of food safety education plays a role in improving the mother's efforts in adopting the behavior as food handler. Its potentially reduce the risk factors and incidence of foodborne diseases. This food safety message is not only important for parents to know and apply, but also for children. Therefore, mother should also transmit the principles of food safety in children with discussion and behavioral examples. Because mothers have a great influence in educating children and are generally closer to children. The child adopts the shared values and behavioral type of the mother

\section{ACKNOWLEDGMENT}

This study was funded by Budget Implementation List (Daftar Isian Pelaksanaan Anggaran/DIPA), Sports Science Faculty, Universitas Negeri Semarang (UNNES). We would like to thank the head of Aisyiyah Preschool, ABA and Kindergarten, Pembina Preschoold and Kindergarten
Semarang, Central Java, Indonesia, all participants in this research. This article was approved by Health Research Ethics Committee (HREC), Universitas Negeri Semarang

\section{REFERENCES}

[1] K.M. Shea, Children and Food Safety. Children's Health and the Environment. www.who.int/ceh/capacity/food.pdf, 2009.

[2] United States Department of Agriculture. Food Safety. https://www.choosemyplate.gov/preschoolers-food-safety, 2016.

[3] Pusat Data dan Informasi Kementerian Kesehatan RI. Schools Foods Sold Outside of Meals. (Situasi Pangan Jajanan Anak Sekolah). Jakarta : Pusat Data dan Informasi Kementerian Kesehatan RI. www.depkes.goid/article/view/15051300001/situasi-pangan-jajajnan anak -sekolah.html, 2015.

[4] N.H. Nordin, , M.R. Razman, S.Z.S. Akaria, "Food safety issues: factor influencing awareness and education at school canteens in Malaysia," International Journal of Management and Applied Science, vol. 1, no. 7 , 2015.

[5] M. Barclay, K. Greathouse, M. Swisher, et.al, "Food safety knowledge, practices and educational needs of students," The Journal of Child Nutrition \& Management, vol. 27, no. 1, 2003.

[6] N.S. Rahayu, F. Firdaus, "Food safety knowledge and practice segmented among housewife in Sleman.," IEEE Transl. Jurnal Unisia, vol. 31, no. 68, 2008.

[7] M. Reicks, A.C. Trofholz, J.S. Stang, M.N.Laska, "Impact of cooking and home food preparation interventions among adults : outcomes and implications for future programs," Journal of Nutrition Education and Behavior, vol. 46., no. 4, 2014.

[8] A. Ovca, M. Jevsnik, P. Raspor, "Food safety awareness, knowledge and practice among students in Slovenia," Journal of Food Control, pp. 144-151, 2014.

[9] J.S. Savage, J.O. Fisher, L.L. Birch, "Parental influence on eating behavior," Journal Law Med Ethics, vol. 35, no. 1, pp. 22-34, 2007.

[10] C. Smithikrai, "Effectiveness of teaching with movies to promote positive characteristics and behaviors," Journal Procedia-Social and Behavioral Science, vol. 217, pp. 522-530, 2016.

[11] A. Bandura, "Health promotion by social cognitive means," Health Education Behavior Journal, vol. 131, no. 2, pp. 143-164, 2004.

[12] G. Martin, and J. Pear, Behavior Modification. What It is and How to Do It?, Boston: Pearson, 2014.

[13] P. Lally, C.H.M. Van Jaarsveld, H.W.W. Potts, and J. Wardle, "How are habits formed: modelling habit formation in the real world," European Journal of Social Psychology, vol. 40, pp. 998-1009, 2010.

[14] D.H. Peters, T. Adam; and O. Alonge, "Implementation research: what it is and how to do it," BMJ, vol. 347, pp. 6753, 2013.

[15] R. Kumar, Research Methodology. A Step-by-Step Guide for Beginner, India : SAGE, 2011.

[16] M.S. Pramono, A. Paramitha, "Children knowledge improvement about health clean live behavior and infectious disease through KIE technique in electronic game form," IEEE Transl. Buletin Penelitian Sistem Kesehatan, vol. 14, no. 4, pp. 311-319, 2011.

[17] M.J. Gomo, "Hygiene behavior descriptions of accelerated junior high school students at SMP 8, Manado," Jurnal e-Biomedik (eBM), vol. 1, no. 1, pp. 503-505, 2013.

[18] S.D. Lepeeleere, I.D.B. Bourdeaudhuij, G. Cardon, M. Verloigne, "The effect of an online video intervention 'Movie Models' on specific parenting practices and parental self-efficacy related to children's physical activity, screen-time and healthy diet: a quasi experimental study," BMC Public Health, vol. 17, no. 366, 2017.

[19] Z. Gizaw, M. Gebrehiwot, Z. Z, "Teka. food safety practice and associated factors of food handlers working in substandard food establishments in gondar town, northwest ethiopia," Int J Food Sci Nutr Diet, vol. 3, no. 7, pp. 138-146, 2014.

[20] A. Ceka, R. Murati, "The role of parents in the education of children," Journal of Education and Practice, vol. 7, no. 5, pp. 61, 2016. 
[21] L. Junghyun, et al, "Correlates of resource empowerment among parents of children with over weight or obesity," Childhood Obesity, vol. 13, no. 1, pp. 63-71, 2017.

[22] S.P. Luby, A.K. Halder, T. Huda, L. Unicomb, R.B. Johnstgon, "The effect of handwashing at recommended times with water alone and with soap on child diarrhea in rural Bangladesh: an observational study," PLos Medicine, vol. 8, no. 6, 2011.

[23] C.P. Borchgrevink, J.M.Cha, S.H. Kim, "Hand washing practices in a college town environment," Journal of Environmental Health, vol. 75, no. 8, 2013. 